\title{
MOŽNOSTI VYUŽITIA VÝSLEDKOV VÝSKUMU A TRANSFER POZNATKOV DO PRAXE
}

\author{
Anna Pad'ourová ${ }^{1 \text { - Iveta Kremeňová }}{ }^{2}$
}

\section{Úvod}

Výskumná činnost' katedry podmieňuje kvalitu realizovanej vzdelávacej činnosti a je neoddelitel'nou súčast'ou jej práce. Evidentným výsledkom je rozsiahla publikačná činnost', organizovanie vedeckých a odborných konferencií a seminárov.

Počas viac ako 45 ročnej existencie katedry sa vytvárali viaceré vedecké školy, ktoré môžeme v súčasnosti zhrnút' nasledovne:

- výskum technológií v spojoch vrátane diagnostikovania procesov a hodnotenia kvality služieb;

- výskum prejavov zákonov a zákonitostí v odvetví spojov;

- skúmanie ekonomiky a manažmentu pôsobiacich na spojových trhoch;

- výskum úloh infraštruktúry v procese rozvoja regiónov a územia.

\section{Výskumná činnost'}

Zložitost' problémov, ktorými sa výskumná činnost' katedry zaoberá, je ovplyvňovaná viacerými zmenami, ako sú:

- zmeny technologického prostredia;

- zmeny vel'kosti a dostupnosti trhov;

- zmeny ekonomiky.

V súvislosti s tým je nevyhnutné prijímat' strategické rozhodnutia o d’alšom smerovaní rozvoja poštových a telekomunikačných sietí a ich produktov, integrácii sietí a služieb, zmien vo vymedzení trhov a vzniku nových trhov v súvislosti s rozvojom elektronických komunikácí́. Súčasne je nutné rozvíjat' riadiace metódy zodpovedajúce takýmto zmenám prostredia. V tomto zmysle ide na jednej strane o orientáciu metód riadenia na siet'ového zákazníka, jeho požiadavky a charakteristiky, na druhej strane o orientáciu na hladanie podstatných zmien $\mathrm{v}$ prostredí a vytváranie nového prostredia v súvislosti s inováciami a difúznymi procesmi.

Katedra v minulosti intenzívne spolupracovala v tejto oblasti s HfV Friedrich List v Drážd'anoch, MADI, MEIS, MIIT Moskva, KIGA Kijev. V súčasnosti nadviazala na túto spoluprácu a rozvinula ju v rámci medzinárodných projektov s TU Dresden, FN Darmstadt a Dieburg (SRN), INT Evry, University Poitiers (Francúzsko), Fontys Eindhoven, Vrije Universiteit Amsterdam, TU Delft (Holandsko).

\footnotetext{
${ }^{1}$ Ing. Anna Pad’ourová, PhD. FPEDAS, ŽU v Žiline, Univerzitná 1, 01026 Žilina, Slovensko, Tel: *421 41 5133129, Fax: *421 415655615

e-mail: anna.padourova@fpedas.uniza.sk

${ }^{2}$ doc. Ing. Iveta Kremeňová, PhD., FPEDAS, ŽU v Žiline, Univerzitná 1, 01026 Žilina, Slovensko, Tel: *421 41 5133100, Fax: *421 415655615

e-mail: iveta.kremenova@fpedas.uniza.sk
} 


\section{Vedecká škola $v$ oblasti spojových technológií}

Súčasná vedecká škola vychádza z dlhodobej orientácie katedry na skúmanie technológií pošty, telekomunikácií a elektronických komunikácií osobitne s dôrazom na kvalitu služieb, diagnostiku procesov a projektovanie nových služieb.

Tematické okruhy výskumu katedry spojené s vedeckou školou do roku 2008 boli zamerané na:

- optimalizáciu a racionalizáciu poštovej siete a služieb vrátane nasadzovania prostriedkov výpočtovej techniky, systémov na podporu rozhodovania v jednotlivých procesoch v pošte;

- diagnostikovanie prostredia pri preprave zásielok spolu s diagnostikou technologických postupov ;

- meranie doby dopravy.

\section{Vedecká škola v oblasti ekonomiky spojov a služieb}

Súčasná vedecká škola vychádza z dlhodobej orientácie katedry na skúmanie prejavov ekonomických zákonov a zákonitostí v odvetviach pošty, telekomunikácií a elektronických komunikácií osobitne s dôrazom na modelovanie vývojových tendencií $\mathrm{v}$ pošte, telekomunikáciách a službách a reguláciu a dereguláciu v spojoch.

Katedra organizuje v spolupráci s d'alšími partnermi pravidelné medzinárodné vedecké konferencie a stretnutia zamerané na riešenie otázok globalizácie, liberalizácie a deregulácie poštových a telekomunikačných trhov. Tematické okruhy riešené v oblasti ekonomiky spojov a služieb do roku 2008 boli zamerané na:

- stanovenie štandardov obslužnosti územia a jej financovania;

- liberalizáciu poštových a telekomunikačných trhov;

- diagnostiku kvality v poštových službách a službách informačnej spoločnosti;

- výskum siet’ových procesov v rámci odvetvových zoskupení firiem a manažment zmien v podmienkach siet’ových organizácií.

\section{Vedecká škola v oblasti ekonomiky a manažmentu podniku}

Uvedená vedecká škola je založená na skúmaní problematiky ekonomického riadenia podnikov pôsobiacich na poštových a telekomunikačných resp. info-komunikačných trhoch, tvorby organizačných a riadiacich štruktúr podnikov na základe ich siet'ových technologických princípov. Jej d’alší rozvoj bol spojený s riešením dôsledkov deregulácie trhov, transformácie ekonomiky a dôsledkami zmien $\mathrm{v}$ správaní sa jednotlivých zúčastnených subjektov na daných trhoch v konkrétnych podmienkach dopravných a spojových podnikov.

V súčasnosti sa uvedená vedecká škola spája s rozvojom poznania v oblasti marketingu a manažmentu spojových podnikov, malých a stredných podnikov, ako aj otázok finančného manažmentu a diagnostiky podniku a podnikatel'ského prostredia, transferu poznania a technológií.

Katedra organizuje pravidelné medzinárodné vedecké konferencie a stretnutia zamerané na riešenie otázok diagnostiky podniku, controlling a logistiku.

Orientácia výskumu katedry v súvislosti s vedeckou školou do roku 2008 je zameraná na:

- ekonomické aspekty a mimoekonomické efekty inteligentných dopravných systémov;

- diagnostika podniku a podnikatel'ského prostredia;

- metódy investičného rozhodovania v spojových podnikoch;

- marketing a manažment v podnikoch služieb;

- výskum výkonnosti poštových operátorov a dopadov liberalizácie trhov na poštových operátorov. 


\section{Vedecká škola $v$ oblasti rozvoja územia, regiónov a infraštruktúry}

Zameranie uvedenej vedeckej školy vychádza $\mathrm{z}$ riešenia úloh informačnej a komunikačnej infraštruktúry $\mathrm{v}$ procesoch formovania regionálneho prostredia, využitia územia a vytvárania podmienok pre regionálny rozvoj, vrátane formulovania regionálnych inovačných stratégií, stratégií zamestnanosti, projektovania špeciálnych info-komunikačných služieb pre podmienky regiónov.

Vedecká orientácia je spojená so zapojením Katedry spojov do spolupráce s regionálnymi orgánmi verejnej správy, neziskovými regionálnymi subjektami, euroregiónmi, ako aj so zapojením sa do budovania týchto inštitúcií v súvislosti s európskymi integračnými procesmi.

Katedra organizuje v spolupráci s d’alšími subjektami (SOPK, Euroregión Beskydy, WSBiF Bielsko Biala, VŠB-TU Ostrava, Mesto Žilina, Bielsko Biala, zástupcovia VÚC a vojvodstiev z PR) pravidelné medzinárodné vedecké konferencie a stretnutia zamerané na riešenie otázok transhraničnej spolupráce a euroregiónov.

Orientácia výskumu katedry do roku 2009 v predmetnej oblasti je zameraná na:

- pol'sko-slovensko-českú transhraničnú spoluprácu, podporu marketingového prieskumu v cezhraničných regiónoch a euroregiónoch, vrátane nástrojov monitoringu spolupráce a diskrepancií;

- modelovanie komunikačnej obsluhy územia územno-správnych celkov.

Výsledky riešenia výskumných úloh sú uplatňované v publikačnej činnosti, prezentované na vedeckých konferenciách a seminároch doma i v zahraničí, $\mathrm{v}$ metodických pokynoch a pomôckach, uplatňovaných vo výučbe a pri riešení regionálnych problémov SR.

Katedra venuje pozornost' väčšiemu zapojeniu svojho pracoviska do takých typov projektov, ktoré nadväzujú na model financovania vedy na Slovensku a na priority štátnej vednej politiky. K takýmto typom projektov radíme:

- štátne programy výskumu a vývoja;

- štátne objednávky;

- $\quad$ programy podporované Agentúrou na podporu vedy a techniky;

- $\quad$ rezortné projekty;

- grantové projekty.

Podl'a uvedený typov projektov Katedra spojov realizuje nasledovné projekty:

Inštitucionálny výskum

- $\quad$ Manažment služieb IT a jeho vplyv na poštové služby;

- Moderné metódy prepojenia a transferu technológii medzi univerzitným a podnikatel'ským prostredím (poštový, telekomunikačný, bankový sektor);

- $\quad$ Analýza a benchmarking úrovne vzdelávacích programov projektového manažmentu;

- $\quad$ Zmeny hodnotových ret’azcov v poštovom sektore;

- $\quad$ Strategický manažment ako podporný faktor rozvoja podniku

7. Rámcový program

- $\quad$ FP7-REGIONS-2007-2 Grant Agreeement Number 202855

- $\quad$ ERDC - Emergence of Research Driven Clusters in Central Eureope;

Projekty grantových agentúr VEGA, KEGA, AV

- Možnosti ohraničenia a vývojové tendencie koncepcie univerzálnej služby v pošte a telekomunikáciách v procese globalizácie;

- Inovačné stratégie v sektore služieb;

- Poskytovanie verejnej telefónnej služby;

- Metódy a techniky strategického manažmentu ako nástroje zvyšovania efektívnosti podniku; 
- Zvýšenie atraktívnosti vysokej školy prostredníctvom marketingovej komunikácie vzdelávacej inštitúcie;

- Aplikácia technológie RFID pre vybrané poštové procesy na podmienky HSS;

- Univerzálna platforma pre inovatívne služby elektronických komunikácií;

- Model manažmentu poznatkov s podporou IKT v projektovom manažmente podniku služieb;

- Difúzne procesy nových mobilných služieb a ich hodnotový ret’azec;

- Využite strategického manažmentu pre podporu rozvoja regiónu;

- Data modeling v procese vzdelávania v počítačovom laboratóriu Katedry spojov;

- Vydanie monografie „Manažment inovácií a technológií v službách“;

- Aplikácia RFID pri sledovaní pohybu diplomových a bakalárskych prác v rámci univerzitného compusu;

- Implementácia nových technológií do vzdelávania (vytvorenie RFID laboratória ako podporného prvku pre vzdelávanie);

- Univerzálna platforma pre inovatívne služby elektronických komunikácií

APVV projekty

- Regionálne dimenzie poznatkovej ekonomiky;

Iné zahraničné projetky

- $\quad$ PMUni - The international Network for Professional Education and Research in Proces and Project Management;

- $\quad$ CEEPUS REDENE-CII-PL Central European Exchange Program for University Studies Regional Development Network - Regionálna rozvojová siet';

Štátny program výskumu a vývoja

- $\quad$ Návrh modelu technologického transferu na Žilinskej univerzite;

- Využitie databáz výskumných prác na vysokých školách pre potreby podnikatel'ského prostredia;

\section{Podnikatel'ská činnost'}

- S Skúšobný zákazník - celoštátny výskum kvality;

- Meranie doby dopravy metódou End to End.

Súčast'ou vedeckovýskumnej činnosti katedry je výchova vedeckých pracovníkov pre vlastnú potrebu, pre potreby rezortu pôšt a telekomunikácií SR, ale aj pre potreby d'alších rezortov v SR i v zahraničí. Doktorandské štúdium aj nad'alej považujeme za jeden z rozhodujúcich ukazovatel'ov kvalitatívnej úrovne katedry. Predpokladáme viac zapájat' doktorandov do riešenia najmä medzinárodných projektov s využitím ich jazykových znalostí, vedeckých a odborných študijných pobytov a do podnikatel'skej činnosti organizovanej katedrou.

Úspešnost’ katedry v oblasti výskumu a vývoja sa kvantifikuje najmä objemom získaných grantových prostriedkov, počtom grantových projektov, počtom vedeckých publikácií a ich ohlasom. Aj nad'alej je hlavným ciel'om katedry pokračovat' v zapojovaní sa do grantových projektov a motivovat' pracovníkov k vedecko-výskumnej činnosti. Každý rok je na katedre organizovaná sút'až Študentskej vedeckej odbornej činnosti, vít’azné práce študentov niekol'kokrát postúpili do celoštátneho kola a do sút’aže, ktorú vypisuje Literárny fond SR.

\section{Grantová podpora}

Príspevok vznikol na základe riešenia výskumných projektov domácich a zahraničných a na základe riešenie projektov, ktoré boli zadávané MDPaT SR, MŠ SR, SP, a.s. 


\section{Literatúra}

[1] Zodpovední riešitelia projektov KS.: Priebežné a záverečné správy ku projektom, ktoré boli odovzdané MŠ SR a zadávatel'om projektov v stanovenom termíne. 